\title{
The European Labour Authority and rights-based labour mobility
}

\author{
Jan Cremers ${ }^{1}$
}

Published online: 14 February 2020

(C) The Author(s) 2020

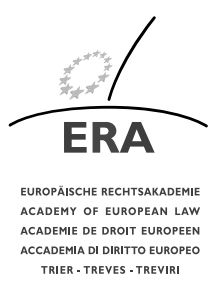

Abstract Regulation (EU) 2019/1149 establishes the European Labour Authority (ELA) as a decentralised operational EU-agency. The ELA has to help individuals and businesses to get most out of the opportunities offered by free movement and to ensure fair labour mobility. According to the Commission, it will serve the double mission of helping national authorities to fight fraud and abuse and making mobility easier for citizens. This article addresses existing problems with labour mobility and analyses reasons for insufficient compliance with local standards and other enforcement problems. The author reflects on the added value and future functioning of the ELA.

Keywords Labour mobility · Labour standards · European Labour Authority · Compliance $\cdot$ Enforcement

\section{Introduction}

In his 2017 State of the Union Address, delivered at the European Parliament in September 2017, European Commission President Juncker announced plans to establish a new European agency, the European Labour Authority (hereafter the ELA), in order to foster fair mobility in Europe. ${ }^{1}$

\footnotetext{
${ }^{1}$ Juncker stated that it is 'absurd to have a Banking Authority to police banking standards, but no common Labour Authority for ensuring fairness in our single market.' https://europa.eu/rapid/press-release_ SPEECH-17-3165_en.htm.
}

\section{J. Cremers}

1 Senior researcher, Tilburg Law School, Cobbenhagenlaan 221, 5037 DB Tilburg, The Netherlands 
The negotiations between the Council of Ministers and the European Parliament on the proposal, which was launched by the Commission in March 2018, ended in the first half of 2019. Regulation (EU) 2019/1149 establishes the office as a decentralised operational agency. The ELA has to help individuals and businesses to get the most out of the opportunities offered by free movement and to ensure fair labour mobility. According to the Commission, it will serve the double mission of helping national authorities fight fraud and abuse and making mobility easy for citizens. The ELA will become operational as of 2020: the inauguration ceremony took place in October 2019. ${ }^{2}$

According to the concluded legal text, the European Labour Authority will support Member States in providing information and services to citizens and business, facilitate cooperation and the exchange of information between Member States, and support them through concerted and joint inspections in order to fight abuse, fraud and undeclared work. The ELA will also carry out the role of mediating between Member States in cases of disputes. The agency will pool and integrate numerous existing EU tools and structures, both by taking them over and by replacing them. The European Labour Authority has a board that consists of one representative of all Member States as well as representatives from the European social partners and the European Parliament. Moreover, the ELA will install a broader stakeholder-group in order to have a regular input from practitioners in industrial relations. ${ }^{3}$

This article addresses the following issues after providing some background information:

- existing problems with labour mobility - an analysis of the reasons for the insufficient enforcement of the law and other problems (confronting both the EU and the Member States);

- the core business and the added value of the ELA (e.g., coverage of all relevant topics, existing structures and tools, new structures and services, pooling, more comprehensive services and synergies); and

- challenges and risks (e.g., gaps, new interfaces, overlaps, complexity, feasibility and resource issues). It also provides a

- short summary and outlook.

\subsection{Some background information}

The ELA's objective is to promote fairness and help strengthen trust in the Single Market, and 'to help individuals and businesses to get most out of the opportunities offered by free movement and to ensure fair labour mobility.' To that effect, the ELA should support the Member States and the Commission in strengthening access to information about rights and obligations in cross-border labour mobility situations and facilitating the solution of cross-border labour market disputes or irregularities. Cross-border activity by workers has increased as a result of migration, whilst the creation of the Single Market has led to intensified temporary labour mobility. Mobile EU citizens move nowadays mainly for employment-related reasons. However,

\footnotetext{
${ }^{2}$ https://ec.europa.eu/social/main.jsp?langId=en\&catId=89\&furtherNews=yes\&newsId=9477.

${ }^{3}$ https://eur-lex.europa.eu/legal-content/EN/TXT/PDF/?uri=OJ:L:2019:186:FULL\&from=EN.
} 


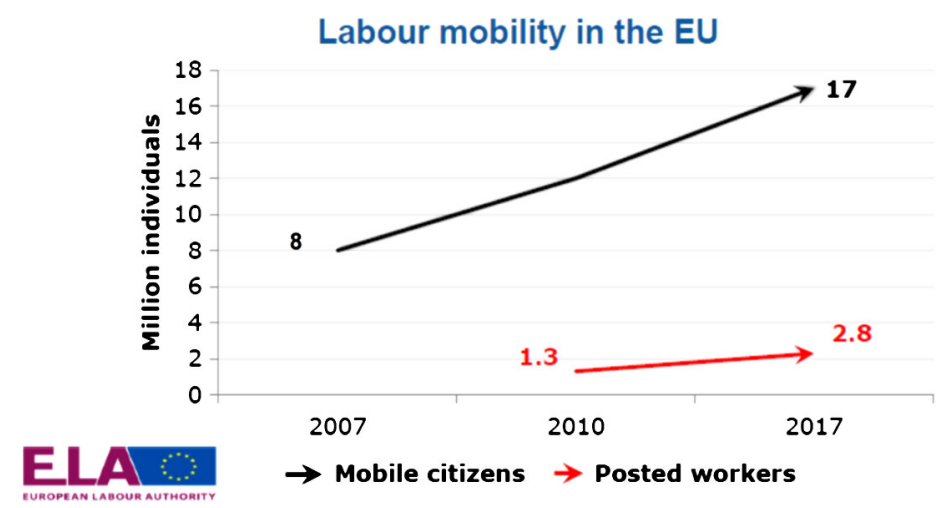

Fig. 1 Data on labour mobility in the EU

labour mobility in the EU is not new. The principle of free movement of workers is enshrined in Article 45 of the Treaty on the Functioning of the European Union (TFEU) and goes back to the earliest principles established in the European Economic Community in 1957. ${ }^{4}$ According to that philosophy, citizens' rights to work in another Member State are grounded on the lex loci laboris, or the regulatory framework of the country where the work is performed. This first type of rights-based labour mobility is increasingly supplemented with temporary labour mobility of posted workers based on the freedom to provide cross-border services and the freedom of establishment (see Fig. 1).

The recent past has shown that the instruments to inform workers about their rights are spread over too many disciplines, whilst checking for irregularities in the social domain and verifying the lawfulness of mobility are restricted by territorial borders and by limited national competences. ${ }^{5}$ As a result, the information that mobile workers have regarding their rights is fragmented. Moreover, national compliance and enforcement authorities face an array of constraints and problems, and control of compliance with rights-based mobility is therefore hampered. Studies have uncovered the work of questionable legal entities, operating in a cross-border context, breaching rules, with regime-shopping and the use of regulatory arbitrage leading to impunity. The experience of inspectors is that fines are weak in an extra-territorial context. Scholars have signalled a lack of effective penalties as social fraud is still not regarded a major offence justifying a European-wide sanction (Cremers [3], Bernaciak [1], ETUC [6]).

\footnotetext{
${ }^{4}$ The 1957 Rome Treaty establishing the European Economic Community contained several provisions to ensure free movement of workers (Treaty of Rome, 1957, Articles 48-51). Free movement of workers meant in particular that workers who were nationals of one Member State had the right to go to another Member State to seek employment and to work there.

${ }^{5}$ A handbook produced by the Senior Labour Inspectors' Committee provides an overview of the dispersed competences: https://circabc.europa.eu/sd/a/d37ac623-cca5-4354-bc8b-64aecd91591c/Introduction. $\% 20 \mathrm{e} \% 20-\% 20 \mathrm{HANDBOOK} \% 20 \mathrm{CROSS} \% 20 \mathrm{BORDER} \% 20 \mathrm{ENFORCEMENT.pdf.}$
} 
Table 1 Identified abuses related to labour mobility (author's compilation)

Working conditions/wages

Business model based on evasion of pay and other wage components

Non-compliance with minimum pay, collectively agreed wages \& working conditions

Underpayment and/or too low scaling / serious mismatch with skill level

Non-payment of overtime bonuses and other allowances; no overtime compensation

Unjustified deductions for lodging and transport

Blurred labour relations
Social security abuses

Business model based on application of low social security contributions

Falsification of A1-form / non-registration in the home country / underpay of contributions

Uninsured workforce / excessively low benefits / pensions

Contribution (in the country of registration) based on excessively low factual remuneration; overtime \& other wage components not included

Unlawful deductions/double pay slips

Bogus self-employment

\subsection{Dealing with labour mobility problems}

Compliance control related to labour mobility is regulated in several intertwined areas. On the one hand, competences to decide on and to control compliance with the regulatory framework of pay and working conditions, social security and tax obligations stem from principles and rights enshrined in EU and national legislation (in the labour, social security and fiscal domain). On the other hand, these competences relate to provisions in agreements resulting from collective bargaining. Table 1 provides a non-exhaustive list of problems that can be encountered in this area (the author's own compilation). What do we know about the functioning of actual information and enforcement practices?

Experience shows that, as soon as a transnational dimension is introduced on local labour markets, compliance control is hampered in most of these areas. In recent decades, this became manifest in several industries, first of all in labour-intensive industries such as construction, manufacturing, shipbuilding, transport and logistics, but in the meantime also in all kinds of services. The use of a foreign (artificial) entity in a cross-border context can lead to the introduction of questionable forms of labour recruitment, with blurred labour relations, the circumvention of social security payments and tax evasion. Freedom of establishment and the free provision of services serve in this context as a breeding ground for artificial arrangements (such as letterbox companies), as these freedoms provide unrestricted entry to European Union Member States' labour markets (Sørensen [8], ETUC [6]). In this paragraph, research results in the area of cross-border mobility, posting of workers and transnational recruitment in the frame of the free movement are briefly listed (largely based on Cremers [5]).

In 2003, a first assessment of the implementation of the Posted Workers Directive (hereafter PWD) examined both the legal context and the practical functioning of the Directive in the framework of the free provision of services. The conclusion was that Member States had hardly developed measures to ensure compliance with the 
posting rules. The responsible national institutions and offices suffered from a lack of staff and competences were too dispersed to guarantee effective control. Verifying the genuine application of labour regulations proved to be arduous. For instance, the fact that under the applicable rules for the coordination of social security, the decisive authority regarding whether a person was employed or self-employed was the sending state, whereas under the Posted Workers Directive, it was the receiving state, caused misunderstandings and a lack of clarity. Checking whether the undertaking in the home country was a genuine undertaking, and pursuing substantial economic operations on a stable basis was very difficult. Host countries had to rely entirely on information of the country of the registered office-and the crucial cooperation and mutual exchange needed in this area were absent. The inspectorates had serious problems in controlling whether posting was just workforce supply or in fact service provision based on a commercial contract. ${ }^{6}$

These findings turned out to be representative of later experiences of the compliance and enforcement offices and the inspectorate. A further investigation in 2010, across twelve countries - with a focus on social and economic disparities between formal legislative or conventional rights and real wages and remuneration, working time, paid leave, living conditions and health and safety-found cross-border recruitment methods ranging from genuine long-established partnerships between contracting partners to completely fake letterbox practices of labour-only recruitment. As regards enforcement practices, competences were spread between too many institutions, the division of labour in one country did not match the division in another and national cooperation between the different institutions involved (i.e., revenue authorities, social security authorities and labour inspectorates) was often lacking. Compared to the 2003 study, the report identified even greater divergences in transposition and application. $^{7}$

The Senior Labour Inspectors Committee (SLIC) carried out a project in 2010 2011 which arrived at comparable conclusions. ${ }^{8}$ The project's aim was to improve the manner in which information is exchanged between labour inspectorates and to ensure enhanced cross border enforcement and mutual assistance in inspection and sanctioning proceedings. The final consensus paper concluded that neither mutual assistance nor cooperation between labour inspectors could rely on a complete and common legal basis. Moreover, inspection services signalled a lack of national networking between all relevant compliance offices and authorities with information spread over several instances, and with demarcations of and limitations to competences that differed in every Member State. The recommendation was to approve mutual assistance at European level in order to ensure the mutual and reciprocal exchange of information and active cooperation among the regulatory authorities from all the Member States. According to the Senior Labour Inspectors Committee this could be reached by the creation of cross-border information systems, and the promotion of all existing forms of mutual assistance and cooperation to the same extent

\footnotetext{
${ }^{6}$ http://www.clr-news.org/wp-content/uploads/2017/11/CLRStudies4-The-free-movement-of-workers. pdf.

${ }^{7}$ http://www.clr-news.org/wp-content/uploads/2017/11/Websummary.pdf.

${ }^{8}$ http://www.empleo.gob.es/itss/ITSS/ITSS_Descargas/Sala_de_comunicaciones/Noticias/2011/Adj_not_ 20111122_6.pdf.
} 
as in other parts of the acquis. Evidence resulting from this cooperation should have the same legal value as evidence obtained from national investigations and the execution of all financial penalties should be guaranteed, in order to enhance cross-border enforcement practices. ${ }^{9}$

A series of projects, led by the French Institut National du Travail, de l'Emploi et de la Formation Professionnelle (INTEFP), organised pilots with joint investigations and exchanges between the inspectorate, social partner organisations, liaison offices and other relevant national actors. ${ }^{10}$ The experiences underlined the necessity of enhanced cooperation between all stakeholders (i.e., the responsible public bodies from all over Europe and social partners). As regards labour mobility in general and the posting of workers in the framework of the free service provision in particular, the project results showed that control of the regularity and the collection of evidence and supporting documents were hindered by fragmented competences and a lack of mandate in the host country. The results raised the question where competence lies for overall compliance control of the regular character of cross-border labour mobility. Deficient competences became manifest as soon as activities referred, rightly or wrongly, to labour mobility in the frame of the freedom of establishment (in another constituency), the contract freedom and the freedom to provide services. ${ }^{11}$

Research in the Netherlands, on the enhanced control and enforcement of labour standards and working conditions, underpinned the problematic relationship between the working conditions of workers involved in temporary cross-border activities and the free provision of services. The research pointed to the decisive importance of the competences and the operational mandate of involved actors and institutions in a cross-border context. ${ }^{12}$

A project, led by the Centre for the Research of Ethnicity and Culture (CVEK) in Bratislava, analysed patterns of labour migration and mobility in the Visegrad countries (V4), with a special focus on the labour mobility of third country workers. ${ }^{13}$ According to the researchers, official data on labour migration was lacking or severely understated (Čaněk and Kall [2]). Institutions had no explicitly defined mandate to tackle labour exploitation or labour rights violations of migrant workers. The capacity of labour inspectorates to investigate labour rights violations was limited because documents provided by employers were the only source of information they could rely on. Neither the linguistic skills of inspectors operating in the field nor instruments were sufficient for a decent assessment.

In the above-cited research, it appears that the activities of most competent national authorities in the social field end at the border, as the mandate of control and enforcement institutions is limited to the national territory. National competent enforcement and compliance authorities are unable to meet their obligations as soon

\footnotetext{
${ }^{9}$ http://www.empleo.gob.es/itss/ITSS/ITSS_Descargas/Sala_de_comunicaciones/Noticias/2011/adj_not_ 20111122_7.pdf.

${ }^{10}$ During the course of the projects that run between 2010 and 2017, only Cyprus and the UK were not involved in the network.

${ }^{11} \mathrm{http}: / / \mathrm{www} . e u r o d e t a c h e m e n t-t r a v a i l . e u /$.

12 https://pure.uvt.nl/portal/files/19807588/Enhanced_report_final_summary.pdf.

13 http://cvek.sk/wp-content/uploads/2018/02/WEB_EN.pdf.
} 
as transnational elements enter the picture. Barriers encountered in compliance activities at national level often originate, on the one hand, in frictions between the juridical frame that the internal market provides for service providers and foreign establishments and the limited territorial mandate of the competent authorities. Existing national compliance arrangements which should protect workers' interests are not adapted to the challenges of enforcement in the internal market. Besides, the monitoring of rules and regulations for cross-border labour mobility and the transnational provision of services with foreign labour is hampered as competences are dispersed over a series of national authorities. Problematic for all stakeholders in a compliance campaign is the lack of effective sanctions. Fines are weak in an extra-territorial context and most countries have no specific enforcement instruments related to labour mobility. The fact that the tackling of artificial arrangements and of fraudulent crossborder labour recruitment very often comes too late or that these practices can pop up repeatedly, leads to serious frustrations. Competence to deregister fraudulent establishments lies outside the competences of compliance authorities and social fraud is still not seen as a major offence that could justify a European-wide sanctioning system.

Based on the practical experiences of the labour inspectorate and other compliance and enforcement authorities, the above-cited researchers recommended that national social and labour inspectors should step up their cooperation, with concerted joint action by national compliance and enforcement authorities seen as key to the fight against fraudulent practices with cross-border labour. Furthermore, the need to fully provide national compliance authorities with competences to check jointly and investigate respect for applicable rules was frequently recommended. Thirdly, there was reference to a need for more effective execution of sanctions (i.e., sanctions with a transnational effect) in cross-border situations.

\section{The core business of the ELA}

In the debates which led to the adoption of the Regulation establishing the European Labour Authority, experiences such as those listed above provided orientation in laying down the core business of the European Labour Authority-namely, improved information provision, the combining of existing instruments relating to cross-border labour mobility and the organisation of joint transnational control activities (European Commission 2018 [7]). At the moment of writing, ELA activities in these areas can be summarised as follows.

\subsection{Increased cooperation in the provision of information}

The need for both increased and enhanced cooperation in the provision of information has been underlined by several experts and practitioners. Such cooperation is hampered by dispersed and fragmented national responsibilities and by related operational difficulties. Regulation (EU) 2019/1149 stipulates, in Article 5, the improvement of the availability, quality and accessibility of information as a basic task of the ELA. In its first meeting (17 October 2019) the ELA Management Board adopted a 
work programme and budget for the Authority for 2019, with a list of preparatory activities, including the setting-up of a working group on information. Pursuant to Article 5 (b) (c) (d) (e) of the founding Regulation, the ELA is to support Member States in applying Regulation (EU) 2016/589, complying with obligations concerning access to and dissemination of information relating to labour mobility and social security coordination legislation, improving the accuracy, completeness and user-friendliness of relevant information sources and services and streamlining the provision of information and services to individuals and employers pertaining to cross-border mobility. The working group has three main tasks: (i) to support the mapping of sources of online information provision to citizens and employers at EU and national level and to analyse information gaps, inconsistencies and action needs on EU and national websites in the labour mobility domain; (ii) to advise the ELA on possible means of support to Member States to carry out the activities established by Article 5 (b) (c) (d) (e) of the founding Regulation, including through the development of standard templates and the exchange of best practices between Member States, and to discuss EU and national strategies on the dissemination of information to citizens and employers.

\subsection{Combining existing instruments related to cross-border labour mobility}

Fragmented competences and excessively strong demarcations of mandates hinder the effective tackling of breaches and abuses. Enforcement activities relating to labour mobility problems and irregularities should combine existing national instruments across all relevant and intertwined policy areas (social legislation, binding collective agreements, social security and tax obligations), leading to the complementary functioning of existing national compliance bodies. The Regulation provides, in several articles, for the integration of some existing bodies (the Expert group on Posting, the EURES European Coordination Office and the European Platform Tackling Undeclared Work) and a clearer division of labour between the ELA and other existing institutions (for instance, the Administrative Commission on Social Security Coordination). In its work programme for 2020, the ELA is set to start the preparations for the smooth integration into the ELA in 2021 of the EURES European Coordination Office and the European Platform Tackling Undeclared Work. The ELA will incorporate over the course of 2020 and 2021 two existing EU bodies, the Technical Committee on the Free Movement of Workers and the Committee of Experts on Posting of Workers. With a view to develop the cooperation agreement mandated by the Regulation (Article 13) the start of discussions with the Administrative Commission on social security coordination is planned.

\subsection{The organisation of joint transnational control activities}

In the above-cited practical cases, it clearly appears with the mandate of control and enforcement institutions limited to the national territory that the activities of most competent national authorities in the social field end at the border. The competence to check the reliability of documents which underpin cross-border activity and, if necessary, to withdraw these documents, is missing. As most cases stem from situations based on EU internal market rules, such as EU freedom of establishment and 
Table 2 Enforcement aspects under the Regulation (EU) 2019/1149 establishing a European Labour Authority

Enforcement beyond national borders

Competences in different policy areas

Tackling of fraudulent establishments

Sanctioning in an extra-territorial context / The EU-wide effect of sanctions

An alert mechanism for stakeholders
- The Authority shall assist Member States and the Commission in their effective application and enforcement of Union law related to labour mobility across the Union and the coordination of social security systems within the Union (Article 1.2).

- The objectives shall be to contribute to ensuring fair labour mobility across the Union and assist Member States and the Commission in the coordination of social security systems within the Union (Article 2), - and (under Article 2.b) facilitate and enhance cooperation between Member States in the enforcement of relevant Union law across the Union, including facilitating concerted and joint inspections.

- If Member States refuse to cooperate, joint inspections will take place only in the participating Member States (Article 8.3).

- The Authority enjoys the most extensive legal capacity accorded to legal persons under the national law of the Member States (Article 3.2). - It shall facilitate cooperation and exchange between national authorities (Article 4.b).

- Concerted, joint inspections are carried out in accordance with the law or practice of the Member States in which the inspections take(s) place (Article 9.2).

- Several existing structures will be integrated or the cooperation with existing structures will be streamlined (recitals 11, 22, 42, 43, 44; Articles 6, 12, 14).

- If the Authority becomes aware of irregularities in areas of Union law, it shall report to the Commission and the Member States (recital 8, Article 9.9).

- The Authority shall facilitate and support cross-border enforcement procedures relating to penalties and fines (Article 7.1.d).

- Inspections should take place at the request of Member States or upon their agreement to the Authority's suggestion (recital 18). - A request for concerted inspection has to come from one or more Member States (Article 8.1).

- Social partner organisations at national level may bring cases to the attention of the Authority (Article 8.1).

the free provision of services, a EU-legitimised mandate that can be performed by national competent authorities in both the sending and the receiving country seems appropriate. Problems related to labour mobility can only be effectively tackled by an authorised institute with the mandate to exercise any or all of its powers across the EU. Therefore, the ELA should have a broad mandate to detect and investigate, with the competence to take all necessary enforcement measures to bring about the cessation or prohibition of abuses. The authority should legitimise, monitor and supervise the activities of the national compliance offices and instances. The Regulation does not draw this ultimate conclusion (see Table 2). What it does is an inclusion of the promotion of enhanced investigations that go beyond the competence limitations in relevant policy areas, which exist in (some) Member States. In the founding Regulation (in Articles 8 and 9), the ELA is tasked with coordinating and supporting concerted and joint inspections. The Authority will facilitate the conclusion of in- 
spection agreements specifying the terms and conditions of the inspections, and will provide support for carrying out such inspections. However, this is subject to the prior agreement of the participating Member States. In its work programme, the ELA has foreseen the establishment of a working group in early 2020, with the task of defining the rules of procedure when carrying out cross-border inspections, discussing the results and identifying further action needs. The working group will discuss coordination and cooperation arrangements with other relevant agencies or bodies.

\section{Positive aspects, challenges and unsolved issues}

Given the fact that the ELA started late October 2019 with a first ceremonial meeting of the Management Board, a first assessment is of course very premature. But, based on early assessments published by the author (Cremers [4] and [5]), some critical remarks can be made.

\subsection{Positive aspects}

First of all, the Regulation recognises that enhanced enforcement is of the utmost relevance for the functioning of the Single Market. Already in the first recital, reference is made to the free movement of workers, freedom of establishment and the freedom to provide services. Moreover, the Authority is not (only) an instrument relevant for EU social policy, the activity of the ELA goes to the core of the functioning of the Single Market as the ELA has to deal with the practical application of EU law. Article 9.7 of the Regulation talks about 'suspected irregularities in the application of Union law'.

Secondly, the Regulation recognises the problems of dispersed compliance and enforcement activities at national and at EU-level. The EC realises that, as a result of a fragmented division of labour between different national authorities and of intertwined policy areas with different compliance traditions, problems with labour mobility in general and with enforcement in particular can only be successful tackled if the necessary activities take place across borders. Notions of concerted, integrated and joint actions and inspections have a prominent role in Regulation. For this reason, starting with concerted or joint inspections figures among the first priorities in the current work programmes.

Thirdly and strongly related to this, consistency requires risk assessment, monitoring and investigations across disciplines. The ELA can provide a mechanism for dialogue, conciliation and mediation, but it can also organise the exchange of available data and knowhow. This includes the exploration of synergies with other relevant EU initiatives and networks. Article 10 of the Regulation specifies that the Authority shall assess risks and carry out analyses regarding labour mobility and social security coordination, on topics such as labour market imbalances, sector-specific challenges and recurring problems.

Fourthly, the strengthening of the capacity of national authorities, combined with intensified information provisions, is seen as a sine qua non for the promotion of genuine cross-border labour mobility. The Authority has to provide operational assistance, including practical guidelines and training. 
In brief, the necessity of capacity building and strengthening of national compliance bodies have been underlined.

Finally, it is positive that an old demand of the Senior Labour Inspectors Committee has, to a certain extent, been met. Article 9.7 says that it shall be possible to use information collected during concerted or joint inspections as evidence in legal proceedings in the Member States concerned, in accordance with the law or practice of the relevant Member State.

\subsection{Challenges and unsolved issues}

Some unsolved issues in the Regulation have to be mentioned here.

- The legal competences of the Authority

The scope of the ELA's competences and the broader legal basis for its work are only modestly reflected in the relevant articles of the Regulation. The original proposal widened the scope to issues of EU law 'beyond the scope of its competences'. Reference to the right of establishment 'under the conditions laid down for its own nationals by the law of the country where such establishment is effected' (Article 49 TFEU) and to the freedom to provide services 'under the same conditions as are imposed by that State on its own nationals' (Article 57) would add core elements of the Single Market acquis to the scope of the ELA. Based on the same reasoning, reference to the prevention of fraud and unfair competition, as formulated in several parts of the acquis, could further broaden the scope of competences. For example, obligations regarding administrative cooperation, stemming from Directive 2006/123/EC of the European Parliament and the Council (Chapter VI), interfere directly in the work of the Authority and, therefore, should be an integral part of the work of the Authority.

- The ELA should facilitate joint inspections

Practical experiences with pilot joint inspection schemes have shed light on the shortcomings of actual cross-border enforcement and mutual assistance activities. The Regulation stops halfway. It is provided that the evidence stemming from exchanged information, mutual assistance and joint inquiries is legally validated in the involved Member States. However, EU-wide authorisation and legitimisation is missing. The ELA provides national compliance authorities with the right to organise and participate in cross-border actions and to set up teams. But beyond this, the mandate to act jointly is not strengthened. There is no EU-wide mandate, comparable to the competence in joint activities of other EU authorities (for instance, powers of inspection and to engage in coordinated actions in the areas of anti-trust law or consumer protection). National compliance authorities that jointly carry out their duties should be empowered to conduct, EU-wide, all necessary inspections of undertakings and related investigations. ${ }^{14}$

\footnotetext{
${ }^{14}$ Regulation (EC) No 2017/2394 of the European Parliament and of the Council of 12 December 2017 on cooperation between national authorities responsible for the enforcement of consumer protection laws and repealing Regulation (EC) No 2006/2004. Council Regulation (EC) No 1/2003 of 16 December 2002 on the implementation of the rules on competition laid down in Articles 81 and 82 of the Treaty.
} 
- Sanctioning and penalties

The ELA proposal will not lead to enhanced practice in fining policy. Article 7.1.d speaks about the task of 'facilitat[ing] and support[ing] cross-border enforcement procedures of penalties and fines'. However, the internal market rules that regulate the economic freedoms so far have few fining or redress mechanisms in the field of cross-border activities. In research on cross-border labour mobility, it has been noted that there is a lack of effective and dissuasive sanctions. And, for instance, based on the Cibeles project, the Senior Labour Inspectors Committee had to conclude that several kinds of penalties were not guaranteed in a transnational context. Moreover, the detection of fraud or infringements in one Member State does not affect the commencement of comparable fraudulent activities in another Member States. The fining policy must fulfil two objectives: to punish and to deter. Breaches cause harm to the economy and long-running breaches undermine the principles of free movement. The least the ELA should do is to develop the main rules for an EU-wide fining policy and for procedures in case of violation of the law.

- Mediation and dispute solving and relevant stakeholders

The mediation mechanism that is proposed is a step forward. However, several questions relating to mediation and dispute-solving are unclear. First, there is the question of access. Given the broad range of national practices that exist in the area of control and enforcement of labour market regularity, the applied procedure should be relatively flexible and open. The regulatory frame for fair labour mobility is built up, on the one hand, by the legislator (and at national level often based on tripartite consultative or advisory structures), on the other hand by the partners in collective bargaining. Most Member States have installed a range of paritarian, sectoral or interprofessional committees which have a mandate to step in as soon as there is an industrial dispute or difference in interpreting agreements and other concluded provisions. These joint bodies are most often composed of representatives of management and labour, and have the task of preventing, solving and settling disputes and conflicts. Social partners have established compliance institutions and counselling offices and cooperate in targeted campaigns. Just like the compliance authorities established by the national legislator, the mandate of these bodies ends at the national border. These stakeholders should have the facility to request the Authority's intervention, notably in situations where labour legislation and legally-agreed working conditions are intertwined.

Another element that is unclear is the legal status of the Authority's decisions and dispute solutions. The decisions should be understood as decisions giving effect to measures taken to bring about the cessation or the prohibition of an infringement.

\section{In summary}

The current work in the initial phase of the ELA is of course dominated by deliberations on procedures and working methods, the recruitment and selection of appropriate staff and the establishment of premises. The planning is that the ELA become operational in the course of 2020. However, looking beyond the heavy load of formalities that will dominate the agenda of the Management Board some reflections on 
the extension of the operational clout remain essential. In practical and operational cooperation, the concerted joint action of national compliance and enforcement authorities is key for the fight against fraudulent practices with cross-border labour mobility. Currently, national compliance authorities lack the competences and legal capacity to check and investigate respect for the applicable rules from a transnational perspective. Moreover, demarcations between competences hinder adequate in-depth compliance control activities. This is the area where the ELA has to demonstrate its added value.

- The work of the European Labour Authority has to legitimise and enhance, from a European perspective, the enforcement of rules and regulations in the Member States. In order to contribute to this aim, the competences and legal capacities of national compliance offices and authorities need to be strengthened. A first step should be the provision of an EU-wide authorisation to act in cases of irregularities that demand EU-wide investigation. In concrete terms, in its activities the ELA will have to provide the joint work of national authorities with cross-border legal capacities. The Authority must take all necessary measures to enable officials from the involved Member States to play an effective role in joint activities. To that end, national officials must be authorised to carry out the duties entrusted to them with the same power as the officials from the Authority.

- In line with this approach, the Authority has to pave the way for an integrated approach. The ELA's activities must make an end to dispersed compliance and enforcement activities at national and EU level. The combined tasks related to matters relating to cross-border labour mobility and the coordination of social security should be complemented with legislative areas not previously covered, such as the genuine provision of services. To this end, it is logical to integrate the tackling of artificial arrangements (related to the freedom of establishment) and cooperation stemming from the fight against fraudulent service providers (chapter VI-the Service Directive) into the Authority's scope of activities.

- The ELA needs to work towards the improvement of fining policy in the area of cross-border breaches of the law. It should lay down the main rules for an EU-wide fining policy and for procedures in case of violations. The Authority has to work out sanction mechanisms, such as the power to suspend activities and take down websites of fraudulent actors, to impose interim measures for widespread infringements with a Union dimension, and to impose penalties proportionate to the cross-border dimension of the practice in question.

Publisher's Note Springer Nature remains neutral with regard to jurisdictional claims in published maps and institutional affiliations.

Open Access This article is licensed under a Creative Commons Attribution 4.0 International License, which permits use, sharing, adaptation, distribution and reproduction in any medium or format, as long as you give appropriate credit to the original author(s) and the source, provide a link to the Creative Commons licence, and indicate if changes were made. The images or other third party material in this article are included in the article's Creative Commons licence, unless indicated otherwise in a credit line to the material. If material is not included in the article's Creative Commons licence and your intended use is not permitted by statutory regulation or exceeds the permitted use, you will need to obtain permission directly from the copyright holder. To view a copy of this licence, visit http://creativecommons.org/licenses/by/4.0/. 


\section{References}

1. Bernaciak, M.: Market Expansion and Social Dumping in Europe. Routledge, London (2015)

2. Čaněk, M., Kall, K. (eds.): Protecting Mobility Through Improving Labour Rights Enforcement in Europe-Transnational Monitoring and Enforcement of Posted Work. Solidar, Brussels (2018)

3. Cremers, J.: In search of cheap labour in Europe. Working and living conditions of posted workers, CLR-Studies 6, Brussels, CLR/EFBWW/International Books (2011)

4. Cremers, J.: Reflections on a European Labour Authority: Mandate, Main Tasks and Open Questions. Friedrich Ebert Stiftung, Brussels (2018)

5. Cremers, J.: The European Labour Authority and Enhanced Enforcement, Policy Department for Economic, Scientific and Quality of Life Policies. European parliament, Brussels (2018)

6. ETUC: A hunters game: how policy can change to spot and sink letterbox-type practices, Brussels (2016)

7. European Commission: Impact Assessment-Accompanying the document Proposal for a Regulation of the European Parliament and of the Council establishing a European Labour Authority, Commission Staff Working Document, Brussels (2018)

8. Sørensen, K.E.: The fight against letterbox companies in the internal market. Common Mark. Law Rev. 52(1), 85-118 (2015) 